\title{
Vertical distribution of heavy metals in wastewater- irrigated vegetable garden soils of three West African cities
}

\author{
Nafiu Abdu • Aisha Abdulkadir • \\ John O. Agbenin • Andreas Buerkert
}

Received: 25 April 2010/Accepted: 17 September 2010/Published online: 2 October 2010

(C) The Author(s) 2010. This article is published with open access at Springerlink.com

\begin{abstract}
Application of untreated wastewater to irrigate urban vegetable gardens is raising serious concern about possible health risks associated with the consumption of these vegetables particularly with regard to the concentrations of heavy metals (HM) in their edible portions. The soil concentrations of cadmium $(\mathrm{Cd})$, chromium $(\mathrm{Cr})$, copper $(\mathrm{Cu})$, nickel $(\mathrm{Ni})$, lead $(\mathrm{Pb})$ and zinc $(\mathrm{Zn})$, were investigated in seven vegetable gardens from the three West African cities of Kano (Nigeria), Bobo Dioulasso (Burkina Faso) and Sikasso (Mali). Also determined were input-output balances of $\mathrm{Cd}$ and $\mathrm{Zn}$ from five vegetable gardens under 30 years of wastewater irrigation in Kano. In these gardens $\mathrm{Cd}$ (2.3-4.8 $\mathrm{mg} \mathrm{kg}^{-1}$ ) and $\left.\mathrm{Zn} \mathrm{(13-285} \mathrm{mg} \mathrm{kg}^{-1}\right)$ concentrations throughout the profile attained unsafe levels. The concentrations of $\mathrm{Cu}\left(0.8-18 \mathrm{mg} \mathrm{kg}^{-1}\right), \mathrm{Cr}$ $\left(1.8-72 \mathrm{mg} \mathrm{kg}^{-1}\right), \quad \mathrm{Ni} \quad\left(0-17 \mathrm{mg} \mathrm{kg}^{-1}\right)$ and $\mathrm{Pb}$ (0.6-46 mg kg-1) were below the safety thresholds for arable soils. Overall, concentrations of $\mathrm{Zn}, \mathrm{Cd}, \mathrm{Pb}$ and $\mathrm{Ni}$ were higher in Kano than in Bobo-Dioulasso and Sikasso. Input-output analyses in Kano indicated
\end{abstract}

N. Abdu - A. Abdulkadir · J. O. Agbenin

Department of Soil Science, Faculty of Agriculture,

Ahmadu Bello University, PMB 1044 Zaria, Nigeria

N. Abdu $\cdot$ A. Buerkert $(\bowtie)$

Organic Plant Production and Agroecosystems Research

in the Tropics and Subtropics, University of Kassel,

Steinstr. 19, 37213 Witzenhausen, Germany

e-mail: tropcrops@uni-kassel.de that irrigation wastewater contributed annually 400-3,700 $\mathrm{g} \mathrm{Cd} \mathrm{ha}^{-1}$ and 7,200-22,300 $\mathrm{g} \mathrm{Zn} \mathrm{ha}^{-1}$, fertilizer 30-2,100 $\mathrm{g} \mathrm{Cd} \mathrm{ha}^{-1} 50-17,600 \mathrm{~g} \mathrm{Zn} \mathrm{ha}^{-1}$, harmattan dust $0.02-0.4 \mathrm{~g} \mathrm{Cd} \mathrm{ha}^{-1}$ and 40-200 $\mathrm{g} \mathrm{Zn}^{-1}$ $\mathrm{ha}^{-1}$ while 300-500 $\mathrm{g} \mathrm{Cd} \mathrm{ha}^{-1}$ and 2,700-4,700 $\mathrm{g} \mathrm{Zn}$ $\mathrm{ha}^{-1}$ came from rainwater inputs. Input-output calculations subtracting the amounts of HM taken out in vegetable biomass and that lost to leaching from total inputs yielded an annual net positive balance of 700-4,160 $\mathrm{g} \mathrm{Cd} \mathrm{ha}^{-1}$ and 9,350-39,700 $\mathrm{g}$ $\mathrm{Zn} \mathrm{ha}{ }^{-1}$. If such balances remain unchanged for another 10-20 years vegetables raised in these garden fields are likely to be unsuitable for human consumption.

Keywords Soil contamination · Urban agriculture · Heavy metal balance

\section{Introduction}

During the last decade the unique agroecological conditions of urban vegetable soils resulting from their input intensity, year-round vegetative cover, soil and hydrological characteristics and their spatial variability (Landsberg 1981; Witting 1991; Hollis 1992; Renger 1993; Businelli et al. 2009) have raised considerable research interests. This is especially so in developing countries where treatment of wastewaters is limited, thus raising concern about HM 
contamination of these soils when irrigated with untreated wastewater and subsequent accumulation in the food chain through plant uptake. Natural soils of the Nigerian savannah are characterized by low HM concentrations due to their high weathering intensity and long period of pedogenesis (Jones and Wild 1975; Agbenin and Latifatu 2004). However, with intensification of urbanization, agricultural activities and industrialization, the extent of HM accumulation has grown. Among such metals cadmium $(\mathrm{Cd})$ and Zinc $(\mathrm{Zn})$ are notoriously mobile and likely to move down through the soil profile to contaminate ground water (Citeau et al. 2003), even though they are easily intercepted by clay particles in subsurface horizons (Fernandez et al. 2007). Citeau et al. (2003) reported lead $(\mathrm{Pb})$ to be largely stable given its solubility rate. Semlali et al. (2004) observed downward migration of $\mathrm{Pb}$ to be negligible. Agbenin (2002) reported lead to accumulate in insoluble forms in a Nigerian savannah soil after 50 years of continuous application of organic manure.

The West African cities of Kano (Nigeria), BoboDioulasso (Burkina Faso) and Sikasso (Mali) are characterized by intensive urban production of vegetables. Even though the cities of Bobo Dioulasso and Sikasso are less populated and industrialized compared to Kano, HM may as well be accumulated in the profiles of these urban garden soils owing to the quality of irrigation water, high inputs of mineral fertilizers (Diogo et al. 2010; Predotova et al. 2010a) and pesticide application. While recent reports stressed the importance of HM loads in irrigation water and soils used for urban vegetable production in Kano (Binns et al. 2003; Abdu et al. 2010), to our knowledge comparative studies of heavy metal pollution of urban vegetable gardens across West African cities are missing.

Balance approaches have been used to assess HM flows in agricultural systems whereby nutrient balances of the surface soil and farm-gate balances are used most often (Bassanino et al. 2007). While the former addresses nutrient flows at the crop scale, the latter quantifies farm-inputs and outputs at the farm level (Velthof et al. 1996; Moolenaar and Lexmond 1998) or at the regional and national scales (Keller et al. 2001; Keller and Schulin 2003; Dach and Starmans 2005).

In view of the above this study aimed at determining the vertical distribution of $\mathrm{Cd}, \mathrm{Cr}, \mathrm{Cu}$,
$\mathrm{Ni}, \mathrm{Pb}$, and $\mathrm{Zn}$ in urban vegetable gardens of three West African cities. Given the elevated concentration of $\mathrm{Cd}$ and $\mathrm{Zn}$ in the Kano urban gardens input-output balances of these two metals ( $\mathrm{Cd}$ and $\mathrm{Zn}$ ) were monitored at the garden level.

\section{Materials and methods}

Description of the study areas and management practices

Seven urban vegetable gardens were selected for this study. They comprised five farmers' gardens in Kano (Nigeria) and one each in Bobo Dioulasso (Burkina Faso) and Sikasso. Kano is located at $12^{\circ} 00^{\prime} \mathrm{N}$ latitude and $8^{\circ} 31^{\prime} \mathrm{E}$ longitude at $480 \mathrm{~m}$ above sea level in the Sudan savannah zone of Nigeria. Rainfall is seasonal and highly variable with an annual mean of $705 \mathrm{~mm}$ recorded during 2008 when this study was conducted. In Kano irrigation of vegetable gardens is intensively practiced along the major rivers which serve as effluent discharge routes for the municipal and industrial wastes produced by local industries.

In Kano the gardens of Koki, Zungeru, Kwakwaci, Gada and Katsina road were evenly distributed across the city and used different wastewater sources. A natural uncultivated reference/control site was selected for comparison of HM contamination in soil profiles. Another well water irrigated garden ('Legal') was also selected as a control in Kano for comparison of vegetable contamination. Management practices and garden sizes were similar across locations. Field plots were mostly between $<0.1$ ha to 0.4 ha and planted to fast growing vegetables such as (Amaranthus caudatus L.), lettuce (Lactuca sativa L.), parsley (Petroselinum crispum) and carrot (Daucus carota ssp. sativus) which is often intercropped with the former ones. Fertilizer use among farmers was only occasional, whereby urea and compound soluble fertilizer in the form of NPK (15-15-15) were the predominant fertilizer types used during the rainy season. However, one farmer (Zungeru) did not use fertilizer throughout the period of the study (November 2007 to April 2009) as he considered wastewater to contain sufficient nutrients for his crops.

In Kano two of the three major industrial estates, Challawa and Sharada, comprise 115 industries 
ranging from tanneries, rubber and plastic factories, textile industries and units dedicated to food processing, metal and wood processing of which most discharge their untreated effluents into the city streams. Egboka et al. (1989) reported a severe contamination of boreholes in Kano with residues from food processing industries and Binns et al. (2003) reported $\mathrm{Cd}$ concentration as high as $30 \mathrm{mg} \mathrm{l}^{-1}$ in urban irrigation water.

Bobo-Dioulasso $\left(11^{\circ} 10^{\prime} \mathrm{N}, 4^{\circ} 19^{\prime} \mathrm{W}, 432 \mathrm{~m}\right.$ asl $)$ has a typical southern Sudanian climate with the rainy season starting in April/May and lasting until October. Annual rainfall for the study year 2008 was $728 \mathrm{~mm}$.

Sikasso $\left(11^{\circ} 19^{\prime} \mathrm{N}, 5^{\circ} 40^{\prime} \mathrm{W}, 375 \mathrm{~m}\right.$ asl $)$ has a typical Guinean climate comprising two main periods: a 5-6 months rainy season from May/June to October and a subsequent 6-7 months long dry season. Annual rainfall during the study year 2008 was $1,271 \mathrm{~mm}$.

Selection of gardens was based on an in-depth survey comprising a GIS-based mapping and farmer interviews about the various sources of irrigation water and management practices across the cities. According to the farmers in Kano and Bobo-Dioulasso, the gardens selected have been under wastewater irrigation for 30 years while gardeners in Sikasso use mostly well water for irrigation. In Bobo-Dioulasso and Sikasso, all gardens suspected to be affected by high HM loads were located in the same area and irrigated with the same water source; therefore only one garden was selected from each city.

Sampling strategy and analytical procedures

\section{Soil and crop sampling}

In Kano at each location duplicate soil samples were taken in 2007 from $0-15,15-25,25-35,35-45$, $45-75,75-100$ and $100-150 \mathrm{~cm}$ depth. In BoboDioulasso and Sikasso, however, sampling occurred only to a depth of 0.8 and $0.7 \mathrm{~m}$ given occurrence of a hard pan and a high water table, respectively. All samples were air-dried, crushed, and passed through a 2-mm mesh sieve prior to analysis.

In Kano, where monitoring of farmers comprised activities such as planting date, frequency, date and duration of irrigation, type and date of fertilizer applied and date of harvest, the year was divided into three seasons: the cold dry season (CDS), the hot dry season (HDS) and the wet season (WS). The CDS lasted from November to January, the HDS from February to May and the WS from June to October. Vegetable cropping was monitored throughout each season and crop and soil samples consisting of 15-20 auger points at 0-20 cm depth from each farmer's garden were collected at each harvest independently of whether a single or more crops were planted throughout the season. For the vegetable sampling, 20-25 subsamples were taken in each of the five gardens just prior to farmers' harvest. The plant samples were washed with clean tap water to remove adhering soil particles. Vegetable samples were oven-dried to constant weight at $65^{\circ} \mathrm{C}$. At Bobo-Dioulasso and Sikasso soil and vegetable samples were only collected once, in November 2007.

Input sources of HM

\section{Irrigation water sampling}

At Kano, about $100 \mathrm{ml}$ of wastewater samples used for irrigation were collected fortnightly from January 2008 to March 2009 (the CDS and HDS) into prewashed $250 \mathrm{ml}$ plastic containers. At each site monthly irrigation water samples were pooled per season yielding a total of three irrigation wastewater samples per year. Two drops of concentrated $\mathrm{HCl}$ were added to each sample to suppress microbial activity followed by refrigerator storage until analysis.

\section{Atmospheric deposition and rain water collection}

In Kano rain and dust samples were collected during the wet and dry seasons. To this end bulk deposition collectors were made of a $0.1 \mathrm{~m}^{3}$ plastic container and mounted in each of the five gardens at $2 \mathrm{~m}$ above ground level as described by Drees et al. (1993) to minimize potential effects of human activities. The plastic containers were covered with a white cotton mesh to reduce contamination from bird droppings, trees and other unwanted materials. The dust in the trap was collected into a clean plastic bag using a clean brush after removing the cotton mesh. Dust samples were collected every week from December 2007 to April 2008 and monthly samples were pooled 
by season yielding three samples per year and location. Rain samples were collected immediately after each rainfall event during three rainy days in August 2008 yielding a total of three rainfall samples per year and mixed with two drops of concentrated $\mathrm{HCl}$ to suppress microbial activity prior to refrigeration until analysis.

\section{Fertilizer sampling}

Representative samples of NPK and urea fertilizers were collected at each application event in the specific gardens in triplicate, ground and stored until analysis.

\section{Output of HM}

\section{Estimation of crop yield}

Harvested amaranthus, lettuce and parsley were typically packed in bundles and carrots in sacks prior to being taken to local markets. Total harvested biomass per unit area was estimated by measuring the dry weight of five bundles of amaranthus, lettuce and parsley and of five sacks of carrot harvested from approximately $7.5 \mathrm{~m}^{2}$. The average weight obtained was then multiplied by the total number of bundles or sacks harvested.

\section{Leaching losses of metals}

Following the description of Bischoff (2007), Lang and Kaupenjohann (2004) and Predotova et al. (2010b), in all five gardens of Kano HM leaching was estimated using PVC cartridges of $0.1 \mathrm{~m}$ height and $0.103 \mathrm{~m}$ diameter with a nylon net at the bottom. The PVC cartridges were filled with an anion cation exchange resin-sand mixture and installed according to the guidelines of TerrAquat Consultancy (Stuttgart, Germany; www.terraquat.com), the patent holder of this method. The tubes were left buried for 10 months (December 2007-October 2008).

\section{Chemical analyses}

Particle size distribution was determined by the hydrometer method following dispersion of the soil with calgon solution (Gee and Bauder 1986) and cation exchange capacity (CEC) was determined by extracting the soil with silver-thiourea solution as described by van Reeuwijk (1993). Soil pH was measured in 1:2.5 soil:water suspension using a glass electrode $\mathrm{pH}$ meter and organic carbon (OC) content of the soil was determined by dichromate oxidation method (Nelson and Sommers, 1986). For total soil N and $\mathrm{P}, 1 \mathrm{~g}$ soil sample was digested with a mixture of $\mathrm{H}_{2} \mathrm{SO}_{4}$-salicylic acid- $\mathrm{H}_{2} \mathrm{O}_{2}$ using selenium as a catalyst. Total $\mathrm{N}$ was measured colorimetrically in the digest using the Bertholet reaction (Chaney and Marbach 1962) with an N-autoanalyzer (TECHNICON AAII, TechniCon Systems, Emeryville, CA, USA) and total $\mathrm{P}$ was determined by the molybdateblue method of Lowry and Lopez using ascorbic acid as a reductant (van Reeuwijk 1993).

For heavy metal analysis, $1 \mathrm{~g}$ each of soil, plant, and dust samples was digested with concentrated $\mathrm{HNO}_{3}$ (puriss, p.a. 65\%; Sigma-Aldrich Corp., St. Louis, MO, USA) and $\mathrm{HCl}$ (37\%, Sigma-Aldrich Corp.) at $80^{\circ} \mathrm{C}$ following the procedure described by Lim and Jackson (1986). Fertilizer samples were digested in a beaker with concentrated $\mathrm{HNO}_{3}$ according to the procedure of the Association of Official Analytical Chemists (Williams 2000). The beakers were swirled gently until white fumes indicated full digestion. The digest was cooled to ambient temperature, filtered and adjusted to $50 \mathrm{ml}$ with distilled water prior to analysis. The water samples were swirled with concentrated $\mathrm{HNO}_{3}$ at $80^{\circ} \mathrm{C}$ until the solution turned white. Finally the digest was filtered through Whatman No. 42 and diluted to $50 \mathrm{ml}$ with distilled water prior to analysis. Concentrations of $\mathrm{Cd}, \mathrm{Cr}, \mathrm{Cu}, \mathrm{Ni}, \mathrm{Pb}$ and $\mathrm{Zn}$ were determined by atomic absorption spectrophotometry (AAS; Model AA 6680, Shimadzu, Kyoto, Japan).

\section{Resin extraction}

After removal from the soil the resin-sand mixture in the cartridge was separated into four layers to obtain an element concentration profile for each cartridge (Bischoff et al. 1999). A sub sample of exactly $30 \mathrm{~g}$ was weighed from each layer into an extraction bottle and extracted four times by mechanical shaking with $100 \mathrm{ml}$ of $2 \mathrm{M} \mathrm{HCl}$ for $16 \mathrm{~h}$. The solution was decanted into a beaker and the supernatant solution filtered into a plastic vial. Cadmium and $\mathrm{Zn}$ were determined by AAS. 


\section{Quantification of HM balance}

Heavy metal balances were established for each garden based on inputs and outputs. Major sources of these inputs and outputs were irrigation water, fertilizer, rainwater, atmospheric dust, crop removal and leaching losses.

The quantity of irrigation water used throughout the life cycle of each crop was estimated based on the discharge rate of the irrigation pumps, length of irrigation per day and frequency of irrigation for the individual crops. The amount of water was multiplied by the concentration of $\mathrm{Cd}$ and $\mathrm{Zn}$. Cadmium and $\mathrm{Zn}$ concentrations in rain water $\left(\mathrm{mg} \mathrm{l}^{-1}\right)$ were converted to $\mathrm{kg} \mathrm{ha}^{-1}$ by multiplication with the amount of annual rainfall. The $\mathrm{Cd}$ and $\mathrm{Zn}$ input through dust deposition were calculated by multiplying the concentration of dust in $\mathrm{g}$ by a yearly estimated dust input of $936 \mathrm{~kg} \mathrm{ha}^{-1}$ dust from an average weekly dust deposition of $0.18 \mathrm{~g}$ collected per $0.1 \mathrm{~m}^{2}$. The total metal content in the harvested biomass was estimated from the metal concentrations of the crops and the harvested dry matter.

\section{Soil metal balance calculation}

In this study, measured input variables were irrigation water and atmospheric deposition in the form of rainfall and dust (Eq. 1):

$$
\begin{aligned}
\Delta \mathrm{SS}_{\mathrm{HM}}= & {\left[\mathrm{IW}_{\mathrm{HM}}+\mathrm{RW}_{\mathrm{HM}}+\mathrm{D}_{\mathrm{HM}}\right] } \\
& -\left[\mathrm{CR}_{\mathrm{HM}}+\mathrm{L}_{\mathrm{HM}}\right]
\end{aligned}
$$

where $\Delta \mathrm{SS}_{\mathrm{HM}}$ is the balance of heavy metal (HM), $\mathrm{IW}_{\mathrm{HM}}, \mathrm{RW}_{\mathrm{HM}}$ and $\mathrm{D}_{\mathrm{HM}}$ are measured inputs of HM through irrigation water, rainwater and dust deposition, respectively; $\mathrm{CR}_{\mathrm{HM}}$ is the measured crop removal of $\mathrm{HM}$ and $\mathrm{L}$ HM denotes losses of $\mathrm{HM}$ through leaching. All data are in $\mathrm{g} \mathrm{ha}^{-1}$ year $^{-1}$.

\section{Statistical analysis}

Computed metal balances for each crop were expresed on a hectare basis. Analysis of variance (ANOVA) was conducted using the General Linear Procedure (PROC GLM) and seasonal differences in HM concentration of soil and crop was determined using Least Significant Difference $\left(\mathrm{LSD}_{0.05}\right)$ tests. Independent variables were season and location, while dependent variables comprised HM concentration in soil and crop samples. Simple correlation analysis was used to relate the change in HM content at each soil depth to the calculated HM balance. All analyses were conducted using SAS 9.2 (SAS 2007) and Microsoft Excel (2003).

\section{Results and discussion}

Distribution of HM in the soil profiles

Heavy metal concentrations ranged from 2.3 to $4.0 \mathrm{mg} \mathrm{kg}{ }^{-1}$ for $\mathrm{Cd}$, from 2.6 to $50.1 \mathrm{mg} \mathrm{kg}^{-1}$ for $\mathrm{Cr}$, from 4.9 to $13.6 \mathrm{mg} \mathrm{kg}^{-1}$ for $\mathrm{Cu}$, from 3.3 to $12.4 \mathrm{mg} \mathrm{kg}^{-1}$ for $\mathrm{Ni}$, from 1.7 to $16.5 \mathrm{mg} \mathrm{kg}^{-1}$ for $\mathrm{Pb}$ and from17.4 to $233 \mathrm{mg} \mathrm{kg}^{-1}$ for $\mathrm{Zn}$ (Figs. 1 and 2) whereby concentrations of $\mathrm{Cr}, \mathrm{Cu}, \mathrm{Ni}$, and $\mathrm{Pb}$ were below the threshold levels for agricultural soils as given by the EU and CCME (2001; Table 1). Across sites most HM concentrations decreased with profile depth, reflecting enrichment at the surface. Higher concentrations of some HM at lower profile depth likely reflected the effects of leaching-related translocation. Cadmium concentrations were with sometimes $>3 \mathrm{mg} \mathrm{kg}^{-1}$ at the bottom of the profile well above safety limits but lower than the $5.3 \mathrm{mg} \mathrm{kg}^{-1}$ reported by Awode et al. (2008) and far below the mean value of 10.3 reported by Mashi and Alhassan (2007) from Kano.

At the Gada site $\mathrm{Cd}$ concentration ranged from 3.7 to $4.8 \mathrm{mg} \mathrm{kg}^{-1}$ and $\mathrm{Zn}$ levels were with $233 \mathrm{mg} \mathrm{kg}^{-1}$ in the surface horizon surprisingly high (Fig. 2). Affinity of metals to organic matter (Agbenin 2002) could be responsible for this surface enrichment because of the relatively high OC concentration in the topsoil.

In Bobo-Dioulasso and Sikasso the concentrations of HMs were often several times lower than in Kano. In the former city, $\mathrm{Cd}$ concentrations ranged from 0.35 to 0.46 and 0.46 to $0.59 \mathrm{mg} \mathrm{kg}^{-1}$, respectively, as compared to the lowest concentration value of $2.3 \mathrm{mg} \mathrm{Cd} \mathrm{kg}{ }^{-1}$ in Kano (Fig. 1). Zinc concentrations were up to 20 times higher in Kano than in Bobo-Dioulasso and Sikasso (Fig. 2). However, $\mathrm{Cr}$ concentration in the surface layer of the vegetable garden in Sikasso was with $67 \mathrm{mg} \mathrm{kg}^{-1}$ almost $25 \%$ higher than in Kano. As the few industries of Sikasso are dedicated to the processing and packaging of agricultural crops, oil and soap, and unlike tanning 


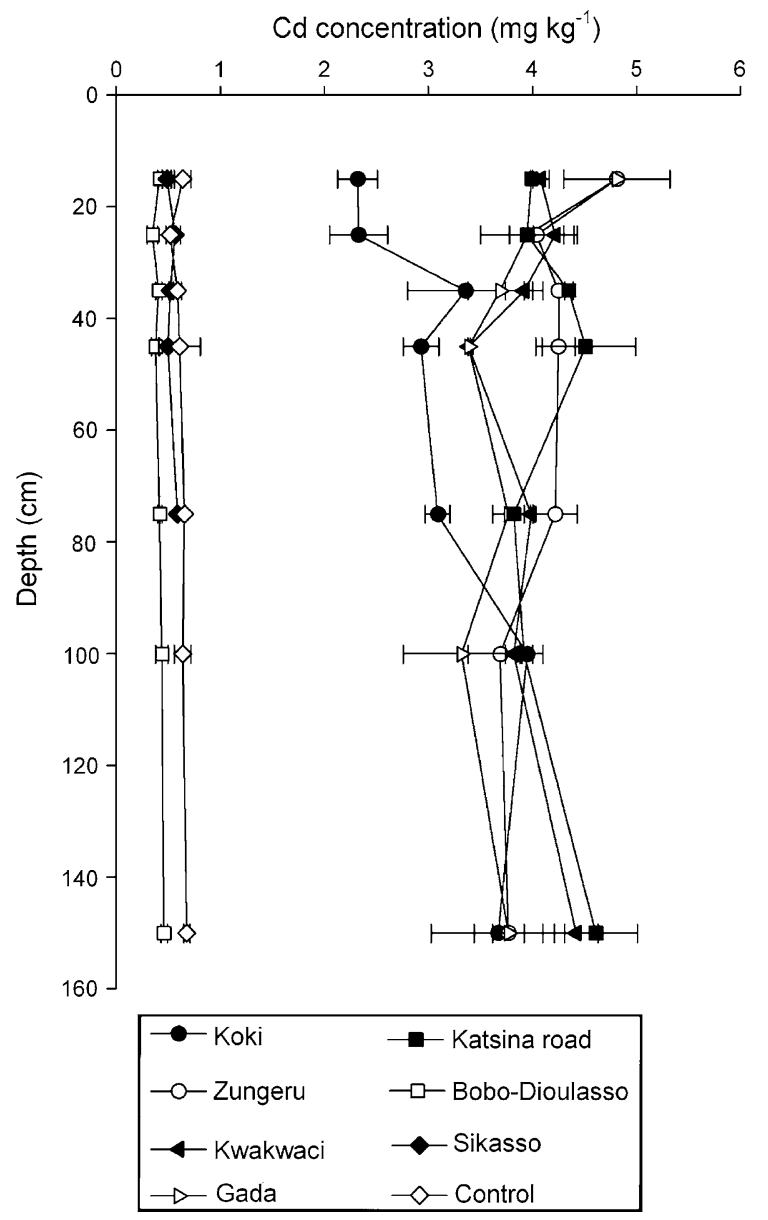

Fig. 1 Distribution of cadmium $(\mathrm{Cd})$ in soil profiles of wastewater irrigated vegetables gardens in three cities of West Africa (Kano, Bobo Dioulasso and Sikasso)

and ginning enterprises do not produce Cr-rich waste, the high values in this Malian city are surprising. In Bobo-Dioulasso, the concentration of $\mathrm{Cd}$ and $\mathrm{Zn}$ decreased with profile depth (Figs. 1 and 2). As this was similar for the other HMs it may again reflect an anthropogenic origin of the studied HMs in the surface soil. The high concentration of $\mathrm{Cr}$ observed in the control soil as well as in the soils from BoboDioulasso and Sikasso likely reflects its association with the soil parent granite and ultramafic rocks. Changes in redox conditions and other chemical properties of the soil as a result of flooding during irrigation and modification of soil $\mathrm{pH}$ might have helped to change the oxidation state of $\mathrm{Cr}$ in the cultivated soil from the stable $\mathrm{Cr}$ (III) to highly mobile $\mathrm{Cr}(\mathrm{VI})$ leading to a low residual concentration of this metal. Binding to dissolved organic matter

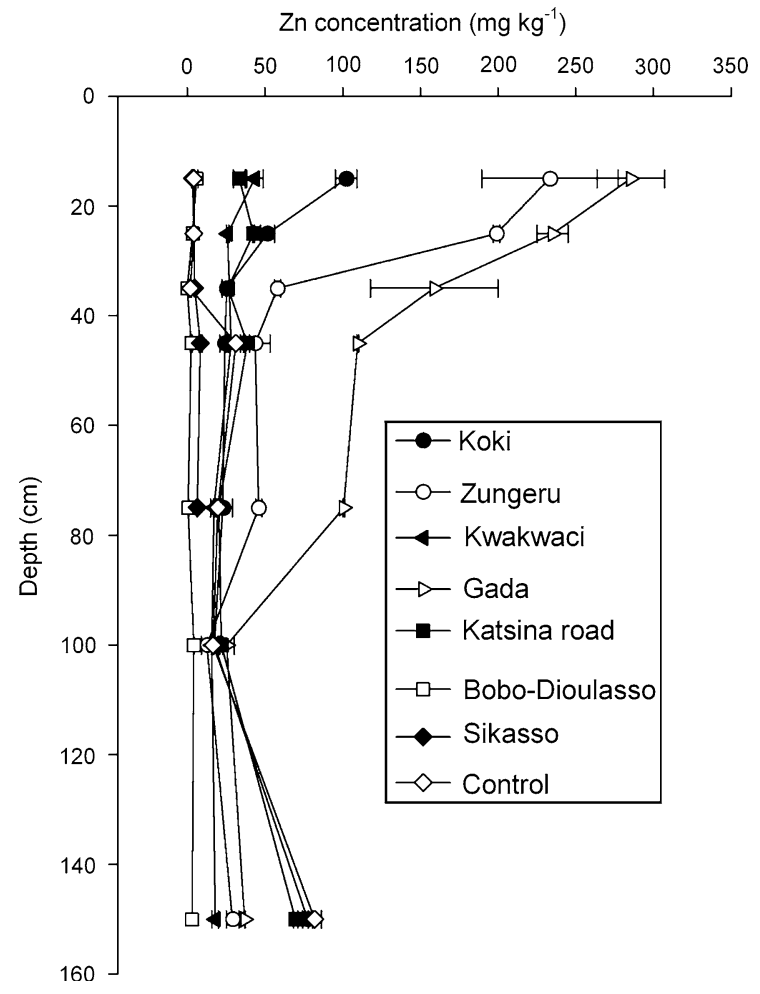

Fig. 2 Distribution of zinc (Zn) in soil profiles of wastewater irrigated vegetables gardens in three cities of West Africa (Kano, Bobo Dioulasso and Sikasso)

Table 1 International threshold values for heavy metals concentrations in soils $\left(\mathrm{mg} \mathrm{kg}^{-1}\right)$

\begin{tabular}{lrlrr}
\hline Heavy metal & \multicolumn{4}{l}{ Regulatory system } \\
\cline { 2 - 5 } & \multicolumn{1}{c}{ EU } & UK & USA & Canada \\
\hline $\mathrm{Cd}$ & 3.0 & 3.0 & 19.5 & 1.4 \\
$\mathrm{Cr}$ & 180.0 & 400.0 & 1500.0 & 6.4 \\
$\mathrm{Cu}$ & 140.0 & $80.0-200.0$ & 170.0 & 63.0 \\
$\mathrm{Ni}$ & 75.0 & $50.0-110.0$ & 210.0 & 50.0 \\
$\mathrm{~Pb}$ & 300.0 & 300.0 & 150.0 & 70.0 \\
$\mathrm{Zn}$ & 300.0 & $200.0-300.0$ & 1400.0 & 200.0 \\
\hline
\end{tabular}

Source: CCME (2001)

could also be responsible for low $\mathrm{Cr}$ concentration in the cultivated soil.

Seasonal variation of heavy metals in Kano

Mean Cd concentration was with $1.4 \mathrm{mg} \mathrm{kg}^{-1}$ highest at the Zungeru site. Mean $\mathrm{Zn}$ concentration in the wastewater irrigated gardens ranged from 90 to 
Table 2 Concentration $\left(\mathrm{mg} \mathrm{kg}^{-1}\right)$ of cadmium (Cd) and zinc $(\mathrm{Zn})$ in five wastewater- and one well water-irrigated vegetable garden soils in Kano, Nigeria

\begin{tabular}{llc}
\hline Location & Cd & \multicolumn{1}{l}{ Zn } \\
\hline Koki $(n=5)$ & $0.7 \pm 0.2$ & $136 \pm 21$ \\
Zungeru $(n=5)$ & $1.4 \pm 0.4$ & $118 \pm 15$ \\
Kwakwaci $(n=5)$ & $0.5 \pm 0.2$ & $90 \pm 32$ \\
Gada $(n=5)$ & $1.0 \pm 0.3$ & $167 \pm 31$ \\
Katsina road $(n=4)$ & $1.2 \pm 0.5$ & $110 \pm 21$ \\
Legal $(n=4)$ & $0.1 \pm 0.01$ & $23 \pm 5$ \\
\hline
\end{tabular}

Data show means \pm one standard error

Table 3 Seasonal change of cadmium (Cd) and zinc ( $\mathrm{Zn}$ ) concentration $\left(\mathrm{mg} \mathrm{kg}^{-1}\right)$ in wastewater irrigated garden soils in Kano, Nigeria

\begin{tabular}{llr}
\hline Season & Cd & \multicolumn{1}{l}{$\mathrm{Zn}$} \\
\hline Cold dry season & $1.1 \pm 0.2 \mathrm{a}^{\dagger}$ & $118 \pm 17 \mathrm{a}$ \\
Hot dry season & $0.9 \pm 0.2 \mathrm{a}$ & $127 \pm 21 \mathrm{a}$ \\
Wet season & $0.3 \pm 0.09 \mathrm{~b}$ & $68 \pm 21 \mathrm{~b}$
\end{tabular}

Data show means \pm one standard error

$\dagger$ Values followed by a different letters are statistically different at $P \leq 0.05$

$167 \mathrm{mg} \mathrm{kg}^{-1}$ with the highest and lowest concentrations observed in Gada and Kwakwaci, respectively (Table 2). Concentration of $\mathrm{Cd}$ and $\mathrm{Zn}$ in the well water irrigated garden soil (Legal) were 0.1 and $22.7 \mathrm{mg} \mathrm{kg}^{-1} \mathrm{Cd}$ and $\mathrm{Zn}$, respectively (Table 2). This indicates the effects of wastewater irrigation on $\mathrm{Cd}$ and $\mathrm{Zn}$ accumulation in the soil. The highest concentration of metals was observed in the CDS followed by HDS (Table 3). Irrigation was most intensive during these seasons given high evaporation rates and crop water demands. During the period from January/February to March vegetable production largely depends on wastewater, therefore it is not surprising that the concentration of both metals in the irrigation water was highest during this season and that the intensity of wastewater use for irrigation largely determines soil accumulation of HMs.

Input sources of $\mathrm{Cd}$ and $\mathrm{Zn}$ to soils

\section{Heavy metal concentration in irrigation water, fertilizer, rainfall and atmospheric dust}

Gardening in Kano is characterized by very low inputs of mineral fertilizers. Irrigation water and
Table 4 Concentration of cadmium $(\mathrm{Cd})$ and zinc $(\mathrm{Zn})$ in irrigation wastewater $\left(\mathrm{mg} \mathrm{l}^{-1}\right)$, rain water $\left(\mathrm{mg} \mathrm{l}^{-1}\right)$ and atmospheric dust $\left(\mathrm{mg} \mathrm{kg}^{-1}\right)$ in Kano, Nigeria

\begin{tabular}{|c|c|c|}
\hline Location/Source & $\mathrm{Cd}$ & $\mathrm{Zn}$ \\
\hline \multicolumn{3}{|l|}{ Koki } \\
\hline Irrigation wastewater & $0.05 \pm 0.01$ & $0.7 \pm 0.02$ \\
\hline Rain water & $0.07 \pm 0.00$ & $0.5 \pm 0.02$ \\
\hline Atmospheric dust & $0.28 \pm 0.02$ & $266.8 \pm 18.4$ \\
\hline \multicolumn{3}{|l|}{ Zungeru } \\
\hline Irrigation wastewater & $0.06 \pm 0.01$ & $0.7 \pm 0.05$ \\
\hline Rain water & $0.04 \pm 0.01$ & $0.6 \pm 0.01$ \\
\hline Atmospheric dust & $0.38 \pm 0.01$ & $63.8 \pm 3.4$ \\
\hline \multicolumn{3}{|l|}{ Kwakwaci } \\
\hline Irrigation wastewater & $0.07 \pm 0.02$ & $0.4 \pm 0.02$ \\
\hline Rain water & $0.05 \pm 0.00$ & $0.4 \pm 0.02$ \\
\hline Atmospheric dust & $0.47 \pm 0.01$ & $87.6 \pm 6.80$ \\
\hline \multicolumn{3}{|l|}{ Gada } \\
\hline Irrigation wastewater & $0.05 \pm 0.00$ & $1.0 \pm 0.34$ \\
\hline Rain water & $0.05 \pm 0.00$ & $0.6 \pm 0.04$ \\
\hline Atmospheric dust & $0.21 \pm 0.10$ & $125.2 \pm 47.2$ \\
\hline \multicolumn{3}{|l|}{ Katsina road } \\
\hline Irrigation wastewater & $0.07 \pm 0.01$ & $0.7 \pm 0.14$ \\
\hline Rain water & $0.04 \pm 0.01$ & $0.4 \pm 0.01$ \\
\hline Atmospheric dust & $0.31 \pm 0.16$ & $132.7 \pm 42.5$ \\
\hline
\end{tabular}

Data show means \pm one standard error

atmospheric depositions were therefore, the major sources of $\mathrm{Cd}$ and $\mathrm{Zn}$ at all sites. Large seasonal concentration changes of HM in irrigation water, rain and dust and site specific differences were observed (Table 4). In the irrigation water average Cd concentration at the five sites in Kano was higher than the $0.01 \mathrm{mg} \mathrm{l}^{-1}$ threshold level set by the FAO. $\mathrm{Zn}$ concentrations were highest in Gada and lowest in Kwakwaci. Even though the mean concentration of $0.87 \mathrm{mg} \mathrm{Zn}^{-1}$ in the irrigation water was less than half of the $2.0 \mathrm{mg} \mathrm{l}^{-1}$ threshold, high annual irrigation rates may have caused $\mathrm{Zn}$ enrichment as indicated by the significant correlation between irrigation water and soil $\mathrm{Zn}$ concentrations $(r=0.45, P<0.05)$. In rain water $\mathrm{Zn}$ ranged from 0.4 to $0.6 \mathrm{mg} \mathrm{l}^{-1}$ which is 2-3 fold lower than what was measured in the dry season dust. At the Gada location $\mathrm{Zn}$ concentration was highest (Table 4) and may reflect the effects of the high concentration of $\mathrm{Zn} \mathrm{44-235} \mathrm{mg} \mathrm{kg}{ }^{-1}$ and $\mathrm{Cd}$ (0.02-0.45 mg kg $\left.{ }^{-1}\right)$ in the dust. Their concentration in NPK fertilizers was $16.5-17.7 \mathrm{mg} \mathrm{Zn} \mathrm{kg}^{-1}$ and 
$0.16-0.22 \mathrm{mg} \mathrm{Cd} \mathrm{kg} \mathrm{kg}^{-1}$ while urea contained $0.03-0.1 \mathrm{mg} \mathrm{Cd} \mathrm{kg}{ }^{-1}$ and $0.13-0.85 \mathrm{mg} \mathrm{Zn} \mathrm{kg} \mathrm{Zn}^{-1}$. The rather high concentrations of HMs in NPK fertilizers may be reflect use of Cd-rich phosphate fertilizers.

Wastewater irrigation led to annual additions of 400-3,700 $\mathrm{g} \mathrm{Cd} \mathrm{ha}^{-1}$ and 7,200-22,300 $\mathrm{g} \mathrm{Zn} \mathrm{ha}^{-1}$ equivalent to 68 and $78 \%$ of the total respective inputs (Table 5). Fertilizer application contributed annually $30-2,100 \mathrm{~g} \mathrm{Cd} \mathrm{ha}^{-1}$ and 50-17,600 g Zn $\mathrm{ha}^{-1}$. Atmospheric wet deposition from rainfall accounted annually for $250-500 \mathrm{~g} \mathrm{Cd} \mathrm{ha}^{-1}$ and 2,700-4,700 $\mathrm{g} \mathrm{Zn} \mathrm{ha}^{-1}$. Cadmium and $\mathrm{Zn}$ inputs from the estimated $934 \mathrm{~kg}$ dust $\mathrm{ha}^{-1}$, instead, were negligible (Table 5). In Kano total atmospheric deposition of $\mathrm{Cd}$ and $\mathrm{Zn}$ were thus 750 - and 23 -fold higher than the $0.5 \mathrm{~g} \mathrm{Cd} \mathrm{ha}^{-1}$ and the $160 \mathrm{~g} \mathrm{Zn} \mathrm{ha}^{-1}$ reported by Azimi et al. (2004) for Versailles, France.

While $\mathrm{Cd}$ concentrations in irrigation and rainwater were above the $0.01 \mathrm{mg} \mathrm{l}^{-1}$ FAO threshold level, those of $\mathrm{Zn}$ were below the $2 \mathrm{mg} \mathrm{l}^{-1}$ threshold but still higher than values reported by Akoto et al. (2008) for five polluted streams in Ghana. At the Gada site, construction activities at about $100 \mathrm{~m}$ from the sampling garden might have contributed to the high $\mathrm{Zn}$ concentration of $1.59 \mathrm{mg}^{-1}$ in the irrigation water (Table 4). Dust at this site also had a $\mathrm{Zn}$ concentration of $207 \mathrm{mg} \mathrm{kg}^{-1}$. The highest concentration of $\mathrm{Cd}\left(0.07 \mathrm{mg} \mathrm{l}^{-1}\right)$ and $\mathrm{Zn}\left(0.96 \mathrm{mg} \mathrm{l}^{-1}\right)$ was measured in irrigation water at Katsina road (Table 4) and might be caused by discharge from a seed and pesticide industry in the vicinity of the sampling site. Although the concentration of HM in the irrigation water may be low, continued use of this wastewater as practiced in Kano can lead to the buildup of HM in soils (Rattan et al. 2002).

\section{Export of metals}

Mean Cd concentration in vegetables ranged from 0.1 to $0.3 \mathrm{mg} \mathrm{kg}^{-1}$ while $\mathrm{Zn}$ export was between 11.5 and $163 \mathrm{mg} \mathrm{kg}^{-1}$. Highest concentration of $\mathrm{Cd}$ and $\mathrm{Zn}$ was recorded in amaranthus and lettuce, respectively (Table 6). Amaranthus with its total dry matter (TDM) of 3.5-28 $\mathrm{t} \mathrm{ha}^{-1}$ led to annual exports of 0.7-2.0 $\mathrm{g} \mathrm{Cd} \mathrm{ha}^{-1}$ and 100-1,700 $\mathrm{g} \mathrm{Zn} \mathrm{ha}^{-1}$ while such values were regligible for carrots with TDM
Table 5 Annual balance of horizontal $\mathrm{Cd}$ and $\mathrm{Zn}$ fluxes for five vegetable gardens in Kano, Nigeria

\begin{tabular}{|c|c|c|}
\hline \multirow[t]{2}{*}{ Location/Source } & \multicolumn{2}{|c|}{ Input-output $\left(\mathrm{g} \mathrm{ha}^{-1}\right.$ year $\left.^{-1}\right)$} \\
\hline & $\mathrm{Cd}$ & $\mathrm{Zn}$ \\
\hline \multicolumn{3}{|l|}{ Koki } \\
\hline Irrigation water & 1,400 & 15,700 \\
\hline Fertilizer (NPK) & 160 & 17,600 \\
\hline Dust & 0.3 & 220 \\
\hline Rainfall & 300 & 4,700 \\
\hline Leaching losses & -300 & $-1,500$ \\
\hline Amaranthus & -1.0 & -600 \\
\hline Carrot & -0.5 & -300 \\
\hline Total balance & 1,560 & 35,800 \\
\hline \multicolumn{3}{|l|}{ Zungeru } \\
\hline Irrigation water & 400 & 7,200 \\
\hline Dust & 0.3 & 54 \\
\hline Rainfall & 500 & 3,900 \\
\hline Leaching losses & -200 & $-1,800$ \\
\hline Amaranthus & -0.7 & -100 \\
\hline Parsley & -0.3 & -100 \\
\hline Total balance & 700 & 9,354 \\
\hline \multicolumn{3}{|l|}{ Kwakwaci } \\
\hline Irrigation water & 3,700 & 22,300 \\
\hline Fertilizer (NPK) & 210 & 15,470 \\
\hline Fertilizer (Urea) & 50 & 770 \\
\hline Dust & 0.4 & 70 \\
\hline Rainfall & 500 & 3,900 \\
\hline Leaching losses & -300 & $-1,100$ \\
\hline Amaranthus & -2.0 & $-1,700$ \\
\hline Carrot & -0.2 & -50 \\
\hline Total balance & 4,158 & 39,660 \\
\hline \multicolumn{3}{|l|}{ Gada } \\
\hline Irrigation water & 700 & 20,000 \\
\hline Fertilizer (Urea) & 80 & 210 \\
\hline Dust & 0.03 & 41 \\
\hline Rainfall & 400 & 4,000 \\
\hline Leaching losses & -200 & $-2,100$ \\
\hline Amaranthus & -3.0 & $-1,700$ \\
\hline Lettuce & -1.0 & -500 \\
\hline Total balance & 976 & 19,950 \\
\hline \multicolumn{3}{|l|}{ Katsina road } \\
\hline Irrigation water & 840 & 13,500 \\
\hline Fertilizer (Urea) & 30 & 50 \\
\hline Dust & 0.02 & 190 \\
\hline Rainfall & 500 & 2,700 \\
\hline Leaching losses & -200 & $-2,800$ \\
\hline Parsley & -1.0 & -900 \\
\hline Lettuce & -1.0 & -600 \\
\hline Total balance & 1,168 & 12,140 \\
\hline
\end{tabular}


Table 6 Crop dry matter yield, cadmium $(\mathrm{Cd})$ and zinc $(\mathrm{Zn})$ concentration and annual removal of $\mathrm{Cd}$ and $\mathrm{Zn}$ in crops from five vegetable gardens in Kano, Nigeria

\begin{tabular}{|c|c|c|c|c|c|c|}
\hline \multirow[t]{2}{*}{ Location } & \multirow[t]{2}{*}{ Crop } & \multirow[t]{2}{*}{ Yield $\left(\mathrm{t} \mathrm{ha}^{-1}\right)$} & \multicolumn{2}{|c|}{ Concentration $\left(\mathrm{mg} \mathrm{kg}^{-1}\right)$} & \multicolumn{2}{|c|}{ Crop removal $\left(\mathrm{g} \mathrm{ha}^{-1}\right)$} \\
\hline & & & $\mathrm{Cd}$ & $\mathrm{Zn}$ & $\mathrm{Cd}$ & $\mathrm{Zn}$ \\
\hline \multirow[t]{2}{*}{ Koki } & Amaranthus $(n=8)$ & 7.1 & $0.1 \pm 0.02$ & $76 \pm 19$ & 1.0 & 600.0 \\
\hline & Carrot $(n=2)$ & 3.0 & $0.2 \pm 0.02$ & $110 \pm 10$ & 0.5 & 300.0 \\
\hline \multirow[t]{2}{*}{ Zungeru } & Amaranthus $(n=6)$ & 3.5 & $0.3 \pm 0.13$ & $47 \pm 11$ & 0.7 & 100.0 \\
\hline & Parsley $(n=3)$ & 1.7 & $0.2 \pm 0.08$ & $79 \pm 5$ & 0.3 & 100.0 \\
\hline \multirow[t]{2}{*}{ Kwakwaci } & Amaranthus $(n=10)$ & 28.1 & $0.1 \pm 0.03$ & $87 \pm 12$ & 2.0 & $1,700.0$ \\
\hline & Carrot $(n=2)$ & 1.8 & $0.1 \pm 0.02$ & $12 \pm 2$ & 0.2 & 50.0 \\
\hline \multirow[t]{2}{*}{ Gada } & Amaranthus $(n=6)$ & 25.8 & $0.2 \pm 0.03$ & $67 \pm 25$ & 3.0 & $1,700.0$ \\
\hline & Lettuce $(n=4)$ & 6.4 & $0.2 \pm 0.07$ & $61 \pm 27$ & 1.0 & 500.0 \\
\hline \multirow[t]{2}{*}{ Katsina road } & Parsley $(n=4)$ & 8.1 & $0.1 \pm 0.01$ & $112 \pm 27$ & 1.0 & 900.0 \\
\hline & Lettuce $(n=2)$ & 4.3 & $0.2 \pm 0.01$ & $164 \pm 91$ & 1.0 & 600.0 \\
\hline
\end{tabular}

Data show means \pm one standard error

yields of 1.8 and $3.0 \mathrm{t} \mathrm{ha}^{-1}$ in Kwakwaci and Koki, respectively (Table 6). The corresponding $\mathrm{Cd}$ and $\mathrm{Zn}$ export was equally low. Leaching of Cd estimated from resin extraction was 200-300 $\mathrm{g} \mathrm{ha}^{-1}$ and of $\mathrm{Zn}$ $1,100-2,800 \mathrm{~g} \mathrm{ha}^{-1}$.

\section{Input-output balances}

High inputs of nutrients through wastewater irrigation have been reported for several studies from West African cities. Diogo et al. (2010) showed large nitrogen $(\mathrm{N})$ surpluses as a result of $\mathrm{N}$ rich wastewater irrigation in Niamey, Niger. Similarly, Khai et al. (2007) reported large $\mathrm{Zn}$ inputs into vegetable gardens of Hanoi, Vietnam through wastewater irrigation. The net surplus of 9,200-39,700 g Zn $\mathrm{ha}^{-1}$ year $^{-1}$ (Table 5) observed in our amaranthus gardens by far exceeded the $650-7,700 \mathrm{~g} \mathrm{ha}^{-1}$ reported by Khai et al. (2007). This largely reflects the level of contamination of the wastewater used for irrigation in Kano. With 9,200 $\mathrm{g} \mathrm{ha}^{-1} \mathrm{Zn}$ surplus was lowest in the garden under parsley and amaranthus. Gardens under amaranthus and carrot production, however, had highest values with $39,700 \mathrm{~g} \mathrm{Zn} \mathrm{ha}^{-1}$ and 4,200 $\mathrm{g} \mathrm{Cd} \mathrm{ha}^{-1}$ (Table 5). In the present study, leafy vegetables seemed to accumulate more HM than fleshy vegetables despite the fact that the fleshy vegetable (carrot) had a longer growing cycle (Table 6). The significance of correlations between the concentration of HMs and HM balances decreased with soil depth (Table 7) reflecting the effects of anthropogenic activities. The close and

Table 7 Relationship between profile distribution of $\mathrm{Cd}$ and $\mathrm{Zn}$ with $\mathrm{HM}$ balances in wastewater irrigated vegetable gardens in Kano, Nigeria

\begin{tabular}{|c|c|c|c|c|}
\hline \multirow[t]{2}{*}{ Soil depth $(\mathrm{cm})$} & \multicolumn{2}{|l|}{ Cd balance } & \multicolumn{2}{|l|}{ Zn balance } \\
\hline & Equation & $r^{2}$ value & Equation & $r^{2}$ value \\
\hline $0-15$ & $y=8 E-10 x^{2}-1 E-05 x+4.02$ & 0.99 & $Y=-6 E-07 x^{2}+0.03 x+3.36$ & 0.98 \\
\hline $15-25$ & $y=2 E-09 x^{2}-5 E-05 x+3.89$ & 0.99 & & 0.51 \\
\hline $25-35$ & $y=-7 E-10 x^{2}-5 E-05 x+3.45$ & 0.93 & & 0.32 \\
\hline $35-45$ & $y=-6 E-10 x^{2}-6 E-05 x+3.03$ & 0.80 & & 0.26 \\
\hline $45-75$ & $y=-2 E-09 x^{2}-5 E-05 x+3.72$ & 0.99 & & 0.48 \\
\hline $75-100$ & & 0.33 & & 0.56 \\
\hline $100-150$ & & 0.43 & & 0.17 \\
\hline
\end{tabular}

Equations were only presented for significant relationship $(P \leq 0.05)$ 
significant relationships observed between HM balance and soil depth largely indicated superfial enrichment of $\mathrm{Cd}$ and $\mathrm{Zn}$. HM accumulation and balance can thus be predicted by changes in HM concentration over a defined length of time. Furthermore, the higher relationship observed for $\mathrm{Cd}$ can be attributed to higher $\mathrm{Cd}$ loading and ease of $\mathrm{Cd}$ movement and translocation in the soil profile as compared with $\mathrm{Zn}$. Such accumulations may in the long term cause environmental and human health risks even if at present those risks seem to be limited except for $\mathrm{Cd}$ and $\mathrm{Zn}$.

\section{Conclusions}

Our study shows $\mathrm{Cd}$ and $\mathrm{Zn}$ accumulation in surface soils of vegetable gardens in Kano (Nigeria). Soil HM concentrations followed the sequence Kano $>>$ Sikasso $>$ Bobo-Dioulasso. Garden-based flux measurements of HM revealed that the major sources of $\mathrm{Cd}$ and $\mathrm{Zn}$ in Kano are wastewater irrigation, atmospheric deposition and NPK fertilizer wherever it was applied. Cadmium and Zn loads may lead to elevated concentrations in marketed vegetables and leach to the groundwater with negative consequences for human health. Legislation is needed to restrict HM loads to soils by limiting HM discharges from industries into wastewater that will continue to be used to irrigate urban vegetable gardens.

Acknowledgments The authors are grateful to the Volkswagen Stiftung, Hannover, Germany for supporting this research financially under the UrbanFood project within the collaborative programme "Resources, their Dynamics, and Sustainability-Capacity-Development in Comparative and Integrated Approaches" (No. I/82 189). The first author also gratefully acknowledges Ahmadu Bello University, Zaria, Nigeria for supporting his studies at the University of KasselWitzenhausen, Germany.

Open Access This article is distributed under the terms of the Creative Commons Attribution Noncommercial License which permits any noncommercial use, distribution, and reproduction in any medium, provided the original author(s) and source are credited.

\section{References}

Abdu N, Agbenin JO, Buerkert A (2010) Fractionation, mobility and bioavailability of cadmium and zinc in urban vegetable gardens of Kano, Northern Nigeria. Environ Monit Assess (submitted)
Agbenin JO (2002) Lead in a Nigerian savanna soil under longterm cultivation. Sci Total Environ 286:1-14

Agbenin JO, Latifatu AO (2004) Competitive adsorption of copper and zinc by a Bt horizon of a savanna Alfisol as influenced by $\mathrm{pH}$ and selective removal of hydrous oxides and organic matter. Geoderma 119:85-95

Akoto O, Bruce TN, Darko G (2008) Heavy metals pollution profiles in streams serving the Owabi reservoir. Afr J Environ Sci Technol 11:354-359

Awode UA, Uzairu A, Balarabe ML, Harrisson GFS, Okunola OJ (2008) Assessment of peppers and soils for some heavy metals from irrigated farmlands on the Bank of river Challawa, Northern Nigeria. Pak J Nutri 2:244-248

Azimi S, Cambier P, Lecuyer I, Thevenot D (2004) Heavy metal determination in atmospheric deposition and other fluxes in northern France agrosystems. Water Air Soil Pollut 157:295-313

Bassanino M, Grignani C, Sacco D, Allisiardi E (2007) Nitrogen balance at the crop and farm-gate scale in livestock farms in Italy. Agric Ecosyst Environ 122:282-294

Binns JA, Maconachie RA, Tanko AI (2003) Water, land and health in urban and peri-urban food production: the case of Kano, Nigeria. Land Degrad Develop 14:413-444

Bischoff W-A (2007) Entwicklung und Anwendung der selbstintegrierenden Akkumulatoren: Eine Methode zur Erfassung der Sickerfrachten umweltrelevanter Stoffe. PhD Thesis, Technical University Berlin, Berlin, Germany

Bischoff W-A, Siemens J, Kaupenjohann M (1999) Solute leaching into groundwater-a comparison of field methods considering preferential flow. Wasser Boden 51:37-42

Businelli D, Massaccesi L, Onofri A (2009) Evaluation of Pb and $\mathrm{Ni}$ mobility to groundwater in calcareous urban soils of Ancona, Italy. Water Air Soil Pollut 201:185-193

Canadian Council of Ministers for the Environment (CCME) (2001) Canadian water quality guidelines for the protection of aquatic life: summary table. Winnipeg, Canada

Chaney AL, Marbach EP (1962) Modified reagents for determination of urea and ammonia. Clin Chem 8:130-132

Citeau L, Lamy I, van Oort F, Elsass F (2003) Colloidal facilitated transfer of metals in soils under different land use. Colloids Surf A Physicochem Eng Asp 217:11-19

Dach J, Starmans D (2005) Heavy metals balance in Polish agronomy: actual state and previsions for the future. Agric Ecosyst Environ 107:309-316

Diogo RVC, Buerkert A, Schlecht E (2010) Horizontal nutrient fluxes and food safety in urban and peri-urban vegetable and millet cultivation of Niamey, Niger. Nutr Cycl Agroecosyst 87:81-102. doi:10.1007/s10705-009-9315-2

Drees LR, Manu A, Wilding LP (1993) Characteristics of aeolian dust in Niger, West Africa. Geoderma 59:213-233

Egboka BCE, Nwankwor GI, Orajaka IP, Ejiofor AO (1989) Principles and problems of environmental pollution of groundwater resources with case examples from developing countries. Environmental Health Perspectives, Nigeria

Fernandez C, Labanowski J, Cambier P, Jongmans AG, van Oort F (2007) Fate of airborne metal pollution in soils as related to agricultural management. 1 . $\mathrm{Zn}$ and $\mathrm{Pb}$ distributions in soil profiles. Eur J Soil Sci 58:547-559 
Gee GW, Bauder JW (1986) Particle-size analysis. In: Klute A (ed) Methods of soil analysis, Part 1. 2nd ed. Agronomy Monogram. 9. ASA and SSSA, Madison, WI. pp 383-411

Hollis JM (1992) Proposal for the classification, description and mapping of soils in urban areas. English Nature, Peterborough

Jones MJ, Wild A (1975) Soils of the West African Savanna, Commonwealth Bureau of Soils, Technical Communication, No. 55, Harpenden

Keller A, Schulin R (2003) Modelling heavy metal and phosphorus balances for farming systems. Nutr Cycl Agroecosyst 66:271-284

Keller A, Steiger B, Van der Zee SEATM, Schulin R (2001) A stochastic empirical model for regional heavy metal balances in agroecosystems. J Environ Qual 30:1976-1989

Khai NM, Ha PQ, Öborn I (2007) Nutrient flows in small-scale peri-urban vegetable farming systems in South Asia-a case study in Hanoi. Agric Ecosyst Environ 122:192-202

Landsberg HE (1981) The urban climate. International geophysics series, vol 28. Academic Press, London

Lang F, Kaupenjohann M (2004) Trace element release from forest floor can be monitored by ion exchange resin tubes. J Plant Nutr Soil Sci 167:177-183

Lim CH, Jackson ML (1986) Expandable phyllosilicate reactions with lithium on heating. Clays Clay Miner 34: 346-352

Mashi SA, Alhassan MM (2007) Effects of wastewater discharge on heavy metals pollution in Fadama soils in Kano city, Nigeria. Bio Environ Sci 20:70-77

Moolenaar SW, Lexmond TM (1998) Heavy metal balances of agro-ecosystems in the Netherlands. Netherlands J Agric Sci 46:171-192

Nelson DW, Sommers LM (1986) Total carbon, organic carbon and organic matter. In: Sparks DL (ed) Methods of soil analysis part 2, chemical methods. ASA, Madison, pp 961-1010

Predotova M, Schlecht E, Buerkert A (2010a) Nitrogen and carbon losses from dung storage in urban gardens of Niamey, Niger. Nutr Cycl Agrocosyst 87:103-114. doi: 10.1007/s10705-009-9316-1

Predotova M, Bischoff W-A, Buerkert A (2010b) Mineral nitrogen and phosphorus leaching in vegetable gardens of Niamey, Niger. J Plant Nutr Soil Sci (in press). doi: 10.1002/jpln.200900255

Rattan RK, Datta SP, Chandra S, Saharan N (2002) Heavy metals and environmental quality: Indian scenario. Fertilizer News 47:21-40

Renger M (1993) In: Puskás I, Farsang A (2009) Diagnostic indicators for characterizing urban soils of Szeged, Hungary. Geoderma 148:267-281

Semlali RM, Dessogne JB, Monna F, Bolte J, Azimi S, Navarro N, Denaix L, Loubet M, Chateau C, van Oort F (2004) Modelling lead input and output in soils by using lead isotopic geochemistry. Environ Sci Technol 38:1513-1521

Van Reeuwijk LP (1993) Procedures for soil analyses; technical paper No. 9, 4th edn. International soil reference and information centre (ISRIC), The Netherlands

Velthof GL, van Erp PJ, Moolenaar SW (1996) Optimizing fertilizer plans for arable farming systems, II. Effects of fertilizer choice on inputs of heavy metals. Meststoffen 1996:74-80

Williams H (2000) In: Kane PF (Ed). Official methods of analysis of AOAC International (17th edn). Gaithersburg, Maryland

Witting R (1991) In: Puskás I, Farsang A (2009) Diagnostic indicators for characterizing urban soils of Szeged, Hungary. Geoderma 148:267-281 